\title{
LOGISTICS SUPPORT AS EFFICIENT BUSINESS AND TRANSPORT
}

\author{
PhD Ljiljana Stosic Mihajlovic Professor \\ The College of Applied Professional Studies, Vranje, Republic of Serbia \\ mihajlovicp@ptt.rs \\ PhD Svetlana Trajkovic, Professor \\ The College of Applied Professional Studies, Vranje, Republic of Serbia, \\ cecasvtr@yahoo.com
}

Original Scientific Paper doi:10.5937/jouproman5-12720

\begin{abstract}
Overcoming physical barriers between buyers and sellers, when the delivery of the goods in question or of passengers when it comes to passenger traffic, is the main task of logistics, practices and skills. When it concerned modern trends clearly we can say that the future has already begun. In this paper, we will point to a growing, you might say revolutionary developments in the field of passenger traffic - crossing the $1000 \mathrm{~km}$ in 10 minutes is no longer a figment of the imagination of talented and imaginative writers of science fiction. This is already a reality that should be expected as a mass phenomenon in the coming short-term period. When Serbia is concerned, progress is evident in logistics - as confirmed by and large, do not now recorded infrastructure projects to be implemented no later than the end of 2020.
\end{abstract}

Keywords: logistics, transport, development

\section{INTRODUCTION}

Here come the better logistics in Serbia - in anticipation of major infrastructure projects, intelligent transport systems and stronger capacity of private operators. For great progress in logistics in Serbia indicates the latest report of the European Commission.

The European Commission's annual progress report for 2016, ${ }^{1}$ Serbia best assessed in the harmonization of regulations in the field of transport, in all its forms, ranging from road, aviation, rail and water. Especially a great progress has been made in the field of railway reform and the reform of the railway undertakings - in terms of opening the railway market, harmonization of legislation in all areas of transport, as well as the progress made in the field of investigation of accidents.

The European Commission notes that the legal framework in the field of road transport is largely adapted to the European. In the application of the harmonized regulations for the transport of dangerous goods, harmonized legislation for road freight and passenger transport, all of which allows access to the market by national and international actors. The EC considers that the further adjustment needed in the field of licensing for transport.

When it comes to water transport, Serbia has also achieved a high level of harmonization of legislation with European laws. Information system on the rivers is operational, complies with the system in EU countries.

The air traffic has been progress in the implementation of the first transitional phase of the Multilateral Agreement on European Common Aviation Area (ECAA).

Of course, the European Commission recommended that in the forthcoming period Serbia should work more on the introduction of intelligent transport systems.

\footnotetext{
${ }^{1}$ http://www.seio.gov.rs/dokumenta/eudokumenta.211.html (pristup 12.12.2016) 


\section{THE NEW "SILK ROAD"}

If Serbia is found in the new "Silk Road", our country has a great chance to become a serious regional trade and transport hub.

In addition to the construction of railroads, another group of preconditions does not require too large investments, and it is mainly related to the efficient organization of rail transport, the quality of transport services, track shipments and the car in real time, a market aspect of the business, developing and nurturing relationships with customers, greater speed, flexibility and elasticity on the market. The introduction route and line trains on major transport routes, particularly to the leading seaports in the region, can the largely to increase the participation of railway transport. If these conditions are not met, our infrastructure, if built, will mainly serve transit flows on the "New Silk Road", and our economy once again will have the necessary support in rail transport. You need to be in Serbia develop logistics centers, freight terminals and intermodal transport systems through which it will be our economy and our market is linked to the European transport network and maritime ports in the Adriatic, Aegean and Black Sea.

National Association of Transport and Logistics emphasizes the lack of adequate staff, lack of favorable loans for investment, increasing competition, an under-developed distribution network, legal restrictions, and limitations in the interpretation and application of regulations.

Domestic logistics companies are facing tough competition imposed by the world and European leading logistics providers.

Both in terms of demands, technology, labor, so and with the commercial aspect of business conditions. After the major crisis that is felt in our country starting from 2008, all business factors have dedicated a large part of its activities, reduce logistics costs. This trend is still present with the prospect of further price cuts. In order to sustain in the market, domestic companies remains to be additional investment and process optimization choices for increasing market share.

The solution of these problems can be seen in two ways:

One is introduction line of the joint operation of professional, vocational and Comorian associations with the requirements of simplification of procedures and processes with regulatory authorities.

The second direction is very fast operation of economic entities to streamline the rationalization of work, uniting in joint projects, joint performance of banks and other financial institutions, enabling the development of its staff and the development of new IT technologies, as well as the specialization for certain tasks and procedures.

Among other things, the problem is visible in the fierce competition in the logistics companies are still weak economic activity. Great offer logistics and transport companies and relatively small volume flows of imports and exports with us, unfair competition and lobbying access to the market, often forcing companies to provide services and do business on the border economy. This results in a lower level of quality of service and inadequate development of logistics solutions and services.

In order to respond to requests for such lower prices of services and to fight for their own profit, logistics companies need to rationalize their own business, to introduce modern IT solutions and to prepare for changes in the economy that are already coming with us. 
For example, earlier they were dominant mass loads and larger amounts of supplies of goods in international flows, while importers and exporters now require smaller and more frequent deliveries of the lot.

They tend to avoid large stocks and reduce the cost of storage of goods, but also the possible negative consequences that may arise due to uncertain demand and unreliable.

It is necessary to point out the growing need for logistics in the online store. The rapid development of online sales, logistics poses new challenges. Looking futuristic, online product sales will change the role and structure of the traditional trade. The time is when producers and consumers can be found in the electronic market and do a sales transaction, without the city traders as intermediaries.

It can be heard that the classic trade disappear over time, it will be sufficient producer, consumer and Logistics, which will implement the distribution of products - from the production site to the place of consumption.

\section{THE DISCREPANCY BETWEEN IMPORTS AND EXPORTS PROBLEM FOR LOGISTICIAN}

Serbia from January to October 2016, exported goods worth EUR 11.07 billion, which is $10.1 \%$ more than in the same period last year, and imported goods worth EUR 14.24 billion, or $5.1 \%$ more on an annual basis. As stated Republic Statistical Office, the total foreign trade of Serbia reached in 10 months of this year, 25.31 billion EUR, which is $7.2 \%$ more than in the same period of $2015 .^{2}$

\footnotetext{
${ }^{2}$ Republika Srbija Republički zavod za statistiku ISSN 0353-9555 SAOPŠTENJE PS10 broj 326 god. LXVI, 05.12.2016. Statistika poslovanja preduzeća

The coverage of imports by exports increased from last year's $74.3 \%$ to $77.8 \%$ in the observed ten-month period. Increase the volume of trade with the world is growing and demand for transport services, which generally can be influenced to reduce their price.

It is known that the prices of transport and logistics services mainly formed on the basis of supply and demand in the market. However, they do not depend only on the volume of import and export flows, but also on the size and structure of the individual delivery of the goods, relations and distances of transportation and a number of other factors. So, for example, had previously been charged with the dominant mass and larger amounts of supplies of goods in international flows, while importers and exporters now require smaller and more frequent deliveries of the lot. He said that companies in this way they want to avoid large supplies and to reduce the cost of storage of goods, but also the possible negative consequences that may arise due to uncertain demand and unreliable.

With this approach, transport and logistics companies have the problem of optimal utilization of cargo and transport capacity, which certainly affects the economy of operations and the price of services. Logistics and freight forwarding companies do consolidation of cargo flows on major transport routes and logistics networks in order to meet the requirements and expectations on the one hand, and organize efficient and economic trends on the other.

Another issue is the asymmetry of import and export cargo flows on certain transport routes, making it difficult to introduce regular liner transport in all modes of transport, which are generally lower prices. In fact, there are routes with a very large volume of export flows and with very low import flows, and are stated problem use reverse trip, economy and price of transport services. 


\subsection{Many share of transport costs in the price of the product}

In October 2016, Serbia exported goods worth EUR 1.14 billion, an increase of $9.2 \%$ compared to the same month of 2015. Imports amounted to EUR 1.49 billion, an increase of $0.7 \%$ than in October last year. ${ }^{3}$

The total export value of the 15 largest domestic exporters was in the period from January to October of 3.2 billion EUR, a Chrysler company Fiat Automobiles Serbia (FCA) still holds the first place, the Ministry of Finance. FCA has made exports worth EUR 929.8 million. In second place is a company with export Hesteel "severe" EUR 280.2 million, and the third is Pirot Tigar whose exports 267.5 million. In fourth place, the tobacco industry Philip Morris (EUR 188.5 million), while the fifth is the Oil Industry of Serbia (NIS), which is placed on the foreign market products worth 187.7 million euros. ${ }^{4}$

The increase in foreign trade turnover in both directions certainly means increased workload for all companies engaged in logistics services. It also means to increase competition, and thus continue to lower prices of services. Currently prices are somewhat higher, because the end is near, when, as a rule, the increased demand.

With regard to the asymmetry of imports and exports, this inequality also produces asymmetric demand and increase in prices of services in imports.

Statistically, in the inland transport sector, the increased demand for services exports in overseas transport in imports. The situation is similar in air transport, because it is necessary to do before the Christmas holidays the delivery of the contracted goods. Increased imports of goods, primarily commercial or consumer goods, leading to an increase in demand, both for storage services, as well as for domestic distribution. "Our goal is to achieve ideal distribution and services and the provision of logistics services $-100 \%$ of the recommended portfolio (goods and services) $100 \%$ quality, $100 \%$ of the buildings during the $100 \%$ of the time. Focus on quality of service, organization, knowledge of the local market, as well as good regional integration of the Western Balkans and better knowledge of the market ... are the attributes that set us apart in the competition." ${ }^{5}$

The lower limit of the price of logistics services companies determine the costs that must be covered, and the upper limit on the market or supply and demand. Where will the price is found between these two figures depends on the business policy of each company. Costs, or the price of logistics and transport, have a lot of participation in the product price.

It ranges up to $20 \%$ for certain types of goods, which in principle is an important space for streamlining and cost savings. However, companies often do not understand all the complexities of logistics operations and expect unrealistically low prices of services. They want compensation for material logistics all other irrationalities in the import and export business, which is not always possible.

\subsection{Free trade agreements encourage trade exchange}

The main trade partners of Serbia in the first ten months of 2016 were Italy (1.8 billion USD), Germany (1.6 billion USD), Bosnia and Herzegovina (USD 1 billion), Romania (677 million USD) and the Russian Federation ( 650 million EUR).

The main partners in imports were Germany (USD 2 billion), Italy (1.7 billion

\footnotetext{
${ }^{5}$ Journal "LOGISTIKA I TRANSPORT", april 2015

- godina X- BROJ 56, ISSN 2334-8399, str. 27
} 
USD), China (1.3 billion USD), Russian Federation (USD 1.2 billion) and Hungary (724 million USD).

Foreign trade was the largest with countries with which Serbia has signed free trade agreements, a member of the European Union make up $64.7 \%$ of total trade of Serbia.

In the exchange with CEFTA countries Serbia has a surplus of about 1.6 billion USD, which is mainly the result of export of agricultural products, metal products, as well as exports of various finished products.

The existing duty free trade agreements have increased market impact of global production and trade companies in the amount of goods that are sold on the Serbian market. At the same time, the domestic logistics companies are facing tough competition imposed by the world and European leading logistics providers, both in terms of technology requires work, and from the perspective of commercial operating conditions.

After a major crisis, which is felt in our country starting from 2008 , all business factors devote a large part of its activities, reduce logistics costs. This trend is even more topical with the prospect of further reduce the cost of logistics. In order to maintain the market to domestic companies remains to be additional investment and process optimization choices to increase market share to the traffic - but not just traffic - infrastructure basic precondition for competitiveness.

\section{INTERNET TRADE LOGISTICS SECTOR CHANGES}

1993, a group of Chinese students to solve 11 November marks the day of singles, when he celebrated solitude and buy gifts for themselves, probably did not even imagine that it sowed the germ of what has in recent years become the biggest "holiday" online shopping on the planet. 34
The resourceful owner of, Jack Ma, took advantage of Dan singles as a reason for big discounts that retailers through its web site during this 24 time offered to customers, and its business provided a good profit from the commission on these transactions. To say that he succeeded.

This year, in fact, only in the first seven minutes of 11 November turnover of a whopping one billion dollars a whole day has passed 17.7 billion USD turnover. Even 40,000 retailers offered more than 6 million unique products to customers who are making millions every minute orders, so no wonder it is sold, for example, more than 3 million handsets, a million watches, about 650,000 television sets, as well as 6,500 cars and 270 tons Teddy bear. And that all this stuff will take care of customers reached 1.7 million suppliers, 400,000 delivery vehicles and 200 aircraft orders to take over the world.

Some of these orders, probably minor, and will end in Serbia. Online shopping, in fact, is slowly gaining momentum and in our country and more and more consumers opt for "click shopping."

This sales channel brings new opportunities but also challenges, as sellers and those whose job it is to ensure that orders arrive as soon as possible where they are intended. ${ }^{6}$

The online store product in a virtual environment, can very quickly find, purchase and pay no matter where the manufacturer, seller and consumer. Only it can not be delivered virtually to the end consumer. It needs to be packaged, transshipped, stored, transported and physically delivered to the final destination.

\footnotetext{
${ }^{6}$ http://www.vecernji.hr/svijet/tijekom-petkapripremili-su-velike-popuste-kinezi-su-dan-samacapretvorili-u-najvecu-rasprodaju-na-svijetu-1127499, pristup 12.12.2016.
} 
Logistics, therefore, is a key factor of successful online sales and the efficiency of logistics operations depends largely on consumer satisfaction with this form of trade.

Companies must create a delivery system for a very different structure of products to a growing number of locations and in a quick and rational way, because customers expect the delivery as soon as possible and at the best price.

Now the logical question arises: What is the success or failure of delivery? When a customer buys online on this only works with so-called one-click. "1-click shopping". Expectations of such a customer as far as supplies are the same - delivery in one click (one-click delivery). Some logistics companies are specialized on the channel of distribution and that they will be successful in the future.

Large retail chains largely recognize the benefits of internet commerce and are willing and necessary investments in logistics. Thus, the Croatian giant Agrokor, through its online store Konzum click only in 2016 carried out more than 100,000 orders and recorded sales growth of more than $40 \%$.

Although the percentage of participation of online trade in Serbia in relation to the entire sale is not high, in recent years there has been tremendous growth but not surprised no plans of our major retailers to invest in online activities. So the company Ahold-Delhaize says that they intend to be the leader of the development of online sales of food in Serbia. - We believe that the Serbian market is developing in this segment and will get a real growth at a time when customers are fully aware of the benefits of buying over the Internet, and when they find out the safety of their food - stated in the company. The plans are based on international experience. In fact, their company is a leader Peapod online grocery sales in the United States, while in the Netherlands this chain Albert Heijns. Also, the online store
Bol.com which, they say, is the biggest reason why Amazon has never penetrated the Dutch market.

Because most online customers comprise individuals, the costs are higher and more effort is needed to consignments were delivered in the shortest possible time. Private individuals can more easily decide to purchase over the Internet which primarily means they have more confidence in this form of sales, and hence the delivery. They're sure that everything purchased by a couple of days can be with them and the advantage is that you can make a payment when you download the product itself referred to in the company.

Online sales of products changes and the role and structure of the traditional trade. At a time when producers and consumers can be found in the electronic market and do a sales transaction, the question that the city as a broker dealer. It can be heard that the classic trade eventually disappear and that with the producers and consumers need only a logistician will realize the physical distribution of products from the production site to the place of consumption.

In this setting, things logistics become an extended arm of the seller and the buyers often see them as employees of the dealers. Failures in delivery can significantly affect the sales and marketing internet sellers, on the other hand fast and reliable delivery can influence that the customer decides to easily purchased on the website of the seller. Therefore, advise logisticians, one should be careful in choosing partners.

\section{INSTEAD OF CONCLUSION}

Moving goods from the factory to the point of sale is a series of complex steps. Modernization and standardization of the movement of products leads to lower costs and losses of goods, improving speed-tomarket, which is essential to your products reach the customer at the right time and in proper condition. 
The revolutionary system of transport of people and goods "Hyperloop One", which was designed by the Danish company BIG, will connect the two cities in the United Arab Emirates in just 12 minutes. "Hyperloop" linking Dubai with key cities around the UAE. In Abu Dhabi, which is located more than 150 kilometers, can be reached in just 12 minutes in Riyadh for 48, 23 Doha, and Muscat for 27 minutes.

Passengers and cargo will be placed in capsules that reach speeds of up to 1,100 kilometers per hour.

Jakob Lange, a partner of BIG, said last month that "Hyperloop" plans to change the lives of people by providing them with the opportunity to choose where they live and work. "Hyperloop" the idea of Elon Musk, founder of the "Tesla Motors", "PayPal" s and company "SpaceX" engaged in the exploration of the universe.

Musk is the concept of "Hyperloop" introduced in 2013, but is not directly involved in its development. "Hyperloop One" has tested its drive technology in Las Vegas earlier this year, where it reached speeds of 187 kilometers in 1.1 seconds.

The main competitor "Hyperloop One" company "Hyperloop Transport Technologies", which is currently building a track in California and negotiating the construction of "Hyperloop's between Budapest, Vienna and Bratislava.

Although state involvement in the construction of transport capacity is evident, however, remained much to be done to the economy received a more complete and better logistic services and the necessary support for a faster and more efficient integration into the European and global commodity flows.

In Serbia, the construction of highways on Corridors 10 and 11 has not yet been completed, shippers expect the construction of new ports and the modernization of existing rail infrastructure works have just started, and the intermodal center in Belgrade waiting for next year.

\section{REFERENCES}

[1] The Republic of Serbia Republic Statistical Office ISSN 0353-9555 COMMUNICATION number 326 PS10 god. LXVI, 12.05.2016. Statistics of business enterprises

[2] Journal "TRANSPORT AND LOGISTICS", April 2015 - X- NUMBER 56 years, ISSN 2334-8399

[3] www.vecernji.hr/svijet/tijekom-petkapripremili-su-velike-popuste-kinezi-su-dansamaca-pretvorili-u-najvecu-rasprodaju-nasvijetu-1127499 